\title{
The lichen flora of the Košice Zoological Garden (E Slovakia)
}

\author{
Margaréta Marcinčinová1*, Pavel Širka² \& Matej Dudáś ${ }^{1}$ \\ ${ }^{1}$ Department of Botany, Institute of Biology \& Ecology, Faculty of Science, P. J. Šafárik University, \\ Mánesova 23, SK-041 54, Košice, Slovakia, margareta.marcincin@gmail.com, dudas.mato@gmail.com \\ 2 Department of Phytology, Faculty of Forestry, Technical University in Zvolen, Zvolen, Slovakia
}

\begin{abstract}
Marcinčinová M., Širka P. \& Dudáš M. (2020): The lichen flora of the Košice Zoological Garden (E Slovakia). - Thaiszia - J. Bot. 30 (2): 197-207.

Abstract: The Košice Zoological Garden offers a wide range of habitats from sunny exposed meadows, hedges and semi-natural well-lit to shaded forests with brooks together with concrete paths and animal cages. To best represent the area, 14 locations were selected. Total of 61 species were recorded. Most of the recorded species were epiphytic or epigeic; epilithic species were limited to a few limestone boulders or anthropogenic substrates. Besides common and widespread nitrophilous species, two recorded species are critically endangered (Arthonia radiata, Parmelia submontana), four are endangered (Evernia prunastri, Flavoparmelia caperata, Graphis scripta and Pleurosticta acetabulum), one is vulnerable (Usnea hirta), while eight are listed as near threatened in Slovakia. The discovery of Bryoria sp. is particularly interesting because of missing records of this species in the area. The lowest altitude of 412 $\mathrm{m}$ a.s.l. for Parmelia submontana in Slovakia was recorded. The region provides a suitable environment for a wide spectrum of lichen species and is worth of our biodiversity conservation concerns.
\end{abstract}

Keywords: lichen diversity, endangered species, air pollution, Carpathians, biodiversity.

\section{Introduction}

Zoological gardens around the world contribute to conservation of biodiversity and protection of the environment in general and have ability to raise public awareness of different species and habitats both exotic and native (Rodrigues-Guerra \& GuillénSalazar 2012). The Košice Zoological Garden enjoys a special position due to its 
location outside of the city centre and its remarkable size. The construction started in 1979 and the ZOO was open to public in 1986. Presently, only one third of the total area is publicly accessible (Matlovičová et al. 2010) with more than 200000 visitors per year. The visitors of the ZOO are only allowed to walk along routes close to animal cages with minimal impact on the rest of the garden. Before it became a ZOO, the area was a part of the agricultural countryside used as pastures, meadows and agricultural forests. Typical habitats include semi-natural Fagus-Carpinus forests with occasional Acer pseudoplatanus, A. platanoides or A. campestre, Betula pendula, Fraxinus excelsior, Pinus sylvestris, P. nigra and Quercus petraea trees and meadows with Prunus spinosa hedgerows. The meadows are used mostly as pastures for horses and cattle belonging to the ZOO, only few areas being not regularly grazed. The adjacent forest is subject to only a little management.

The lichen flora of Košice and its surrounding hills has been poorly investigated. More complex research was carried out in nearby territories, such as the Slovenské rudohorie Mts., the Volovské vrchy Mts., the Čierna hora Mts. and the Slanské vrchy Mts. (e.g. Suza 1949; Pišút \& Liška 1985; Pišút 2002; Bačkor \& Bodnárová 2002; Orthová 2003; Guttová et al. 2017; Goga et al. 2018). The only more recent publications mentioning lichen diversity in the city and its immediate surroundings are those by Bačkor et al. (2003) and Bačkor \& Bodnárová (2002). Bačkor \& Bodnárová (2002) collected Evernia prunastri and Parmelina tiliacea at the Botanical Garden of the University of Pavol Jozef Šafárik in Košice and treated these findings as very rare. Bačkor \& Bodnárová (2002) also recorded Flavoparmelia caperata, Ramalina fastigiata, Vulpicida prunastri, Physcia aipolia and Physcia tenella in the city and its immediate surroundings. Lack of data from this region together with the position of the ZOO on the eastern border of the Čierna hora Mts. (subunit of the Slovenske rudohorie Mts.) and the protection of the environment provided by the ZOO make this area attractive for lichen diversity study. This paper presents the results of the first survey of lichen flora of the ZOO Košice, which is a part of an extensive biodiversity study of the ZOO.

\section{Material and Methods}

\section{Study area}

The Košice Zoological Garden (the ZOO Košice) is located on the outskirts of the city of Košice, Kavečany borough about $8 \mathrm{~km}$ north of the city centre. Area of the ZOO is based in the valley of the Hrubša brook (right tributary of the Hornád River) surrounded by forests of Čierna hora Mts., far from built-up city area. With its area of 289 ha, it is the largest ZOO in Central Europe (Fig. 1). Area of the ZOO consists of various habitats varying from semi-natural beech forests, oak forests, grazed or mowed meadows to synanthropic park greenery and roadsides.

The climate of the area is warm, temperate, and humid, being affected by nearby highlands. The average annual temperature is $7{ }^{\circ} \mathrm{C}$ (Štastný et al. 2017), average precipitation reaches $700 \mathrm{~mm}$ (Faško \& Štastný 2017) with northern wind prevailing. The altitudinal range of the $Z O O$ is between $350-600 \mathrm{~m}$ a.s.l. The study area of the 
Košice ZOO is situated in the Central Hornád valley phytogeographical district (Futák 1984). The geological basin is made mostly of calcareous rocks with sporadic occurrence of metamorphosed limestone (Biely et al. 2017).

\section{Field work}

The field survey was conducted for 3 days $\left(19^{\text {th }}\right.$ June and $7^{\text {th }}$ October 2019 and $14^{\text {th }}$ May 2020) at 14 locations (Fig. 1). The GPS coordinates of the locations were recorded by iPhone SE, later checked for accuracy on Google Maps in WGS-84 system. Maps used in Fig. 1 are based on www.mapy.cz/zemepisna (Fig. 1A) and www.katasterportal.com (Fig. 1C). We have selected locations featuring various types of habitats, such as beech forest, dry oak forest, scrubs between meadows, sun-exposed dry meadows on limestone, rocks and also synanthropic habitats (roadsides, park greenery, walls around animal cages), to serve as true representatives of this heterogeneous region. The collected specimens are stored at the herbarium of Botanical Garden of Pavol J. Šafárik University in Košice (acronym $\mathrm{KO}$ ) or at the herbarium of the ZOO Košice. Specimens were identified by standard microscopy (including UV light) under dissecting and light microscope in watermounted preparations. Chemistry was studied by standard spot reagents. The lichen nomenclature follows Guttová et al. (2013) and Red list data follow Pišút et al. (2001). All names of vascular plants follow Marhold et al. (2007).

The result list consists of alphabetically arranged taxa with a threat category (Pišút et al. 2001), location number and type of substratum. Deposited specimens (if collected) are indicated in square parentheses (in the herbarium of the Botanical Garden [KO] and/or in herbarium of the ZOO Košice [*]). For epiphytic species abbreviations of host wood species were used: AP - Acer pseudoplatanus, APi-Acer platanoides, BP - Betula pendula, CB - Carpinus betulus, FE - Fraxinus excelsior, FS Fagus sylvatica, LD - Larix decidua, MD - Malus domestica, PA - Picea abies, PiS Pinus sylvestris, PS - Prunus spinosa, QP - Quercus petraea, SC - Salix caprea, TC Tilia cordata.

\section{Locations sorted by habitat type:}

Park greenery: 1, 7, 13, 14.

Fagus sylvatica forest: 2, 3, 4, 5, 8, 10.

Sunny, stony meadows: $6,9$.

Well-lit shrubs: $11,12$.

\section{List of locations}

1 - entrance to the ZOO, old apple-tree (Malus domestica) orchard along the road; $48^{\circ} 47^{\prime} 10.7^{\prime \prime} \mathrm{N} 21^{\circ} 12^{\prime} 15.2^{\prime \prime} \mathrm{E}, 395 \mathrm{~m}$ a.s.l.; 19.6.2019

2 - single fallen Fraxinus excelsior tree, near a small brook, partially shaded in Fagus sylvatica forest; $48^{\circ} 47^{\prime} 30.5^{\prime \prime} \mathrm{N} 21^{\circ} 12^{\prime} 02.5^{\prime \prime} \mathrm{E}, 412 \mathrm{~m}$ a.s.l.; 19.6 .2019

3 - Carpinus betulus trees along the road, shaded; $48^{\circ} 47^{\prime} 18.6^{\prime \prime} \mathrm{N} 21^{\circ} 12^{\prime} 23.6^{\prime \prime} \mathrm{E}, 390 \mathrm{~m}$ a.s.I.; 19.6.2019 
4 - forest road, partially shaded, Fagus sylvatica, Pinus sylvestris; $48^{\circ} 47^{\prime} 11.0^{\prime \prime} \mathrm{N}$ $21^{\circ} 11^{\prime} 39.9^{\prime \prime E}, 460 \mathrm{~m}$ a.s.I., 19.6.2019

5 - E exposed forested slopes in Dinopark, shaded; $48^{\circ} 47^{\prime} 24.6^{\prime \prime} \mathrm{N} 21^{\circ} 12^{\prime} 29.2^{\prime \prime} \mathrm{E}, 385 \mathrm{~m}$ a.s.I., 19.6.2019

6 - sunny SE exposed stony meadow (limestone and dolomite); 48 $47^{\prime} 27.2^{\prime \prime} \mathrm{N}$ $21^{\circ} 12^{\prime} 01.6^{\prime \prime} \mathrm{E}, 410 \mathrm{~m}$ a.s.l.; 19.6 .2019

7 - meadow near a playground, planted Picea abies and Larix decidua trees; $48^{\circ} 47^{\prime} 08.5^{\prime \prime} \mathrm{N} 21^{\circ} 12^{\prime} 09.5^{\prime \prime E}, 400$ m a.s.l.; 19.6.2019

8 - forest road, shaded, Fagus sylvatica, Acer pseudoplatanus, occasional limestone boulders; $48^{\circ} 47^{\prime} 09.2^{\prime \prime} \mathrm{N} 21^{\circ} 11^{\prime} 46.9^{\prime \prime E}, 440 \mathrm{~m}$ a.s.l.; 19.6.2019

9 - xerothermic SE-exposed rocky slope (mixed limestone and silicate - artificial pile of stones), in the middle of the ZOO; 48 $47^{\prime} 20.0^{\prime \prime} \mathrm{N} 21^{\circ} 12^{\prime} 16.2^{\prime \prime} \mathrm{E}, 381 \mathrm{~m}$ a.s.I.; 7.10.2019

10 - partially shaded forest road, Fagus sylvatica, Pinus sylvestris with Vaccinium myrtillus; $48^{\circ} 47^{\prime} 10.9^{\prime \prime} \mathrm{N} 21^{\circ} 11^{\prime} 41.2^{\prime \prime} \mathrm{E}, 445 \mathrm{~m}$ a.s.I.; 7.10.2019

11 - shrubs near the ZOO entrance, Prunus spinosa, Swida sanguinea, Acer campestre, partially shaded to well-lit; $48^{\circ} 47^{\prime} 05.2^{\prime \prime} \mathrm{N} 21^{\circ} 12^{\prime} 13.3^{\prime \prime E}, 405 \mathrm{~m}$ a.s.I.; 7.10.2019

12 - hedgerows on the meadow, Prunus spinosa, Acer campestre, Swida sanguinea, Quercus petraea, bright S exposure; 48 $47^{\prime} 00.2^{\prime \prime N} 21^{\circ} 11^{\prime} 52.0^{\prime \prime E}, 470 \mathrm{~m}$ a.s.I.; 7.10.2019 13 - Tilia cordata alley in the middle of the ZOO with occasional Acer platanoides, SE exposure; $48^{\circ} 47^{\prime} 18.0^{\prime \prime} \mathrm{N} 21^{\circ} 12^{\prime} 15.7^{\prime \prime} \mathrm{E}, 385 \mathrm{~m}$ a.s.l.; 7.10.2019

14 - young planted Acer pseudoplatanus tree on the side of the path and old rotten bench made of simple tree trunk, sunny pathway; $48^{\circ} 47^{\prime} 17.236^{\prime \prime} \mathrm{N}, 21^{\circ} 12^{\prime} 11.913^{\prime \prime} \mathrm{E}, 400$ m a.s.I.; 14.5.2020.

\section{Results}

In total 61 taxa in the ZOO Košice were recorded, of which 15 taxa are included in the Red list in various categories: CR (two species), EN (four), VU (one) and LR:nt (eight). Of the recorded species, $64 \%$ were epiphytic, $21 \%$ epilithic and $15 \%$ epigeic. Most of the recorded species were comprised of crustose and foliose lichens (39, resp. $43 \%$ ) and only $18 \%$ were fruticose species. This prevalence of foliose lichens is apparent; families Parmeliaceae, Physciaceae and Teloschistaceae make up $51 \%$ of the recorded species.

\section{List of the recorded species}

Amandinea punctata - 2, 3, 4, 7, 11, 12 (on various trees)

CR Arthonia radiata -3 (CB) [KO, $\left.{ }^{*}\right]$

Arthopyrenia sp. -3 (CB)

Baeomyces rufus - 8, 10 (both soil and moss) [*]

Bilimbia sabuletorum - 9 (moss) [KO]

Bryoria sp. - 14 (small juvenile thallus, wood)

Caloplaca cerinella - 1 (MD) [KO]

Caloplaca crenulatella - 2 (limestone pebble) [KO]

Caloplaca holocarpa - 9 (concrete)

Candelariella aurella - 9 (rock, concrete) 
Candelariella reflexa $-1,2,7$ (on various trees) [KO]

Circinaria contorta $-6,9$ (rock, concrete) $\left[^{*}\right]$

Cladonia chlorophaea -8 (soil)

Cladonia coniocraea - 3, 5, 8 (soil), 10 (wood) [*]

Cladonia fimbriata - 4, 5, 8, 10 (soil) [*]

Cladonia furcata-6, 9, 10 (soil) [*]

Cladonia pyxidata -9 (soil)

Cladonia subulata - 9 (soil) [KO]

Cladonia symphycarpia - 6 (soil) [KO]

EN Evernia prunastri - 1 (SC, MD), 2 (FE), 11 (PS), 12 (PS), 13 (TC), 14 (wood)

EN Flavoparmelia caperata-1 (SC), 2 (PS), 12 (QP), 14 (AP) [*]

EN Graphis scripta - 3, 5 (CB, FS) [KO, *]

Hypogymnia physodes - 2(FE), 7 (PiS), 11 (PB), 12 (PS), 14 (wood) [*]

LR:nt Hypogymnia tubulosa - 7 (PiS, LD), 12 (PS), 14 (wood) [*]

Lecanora chlarotera $-3,10$ (FS)

Lecanora conizaeoides -7 (PiS)

Lecanora dispersa - 9 (rock), 14 (concrete)

Lecanora muralis - 13 (walls, asphalt roads, concrete)

Lecanora pulicaris -2 (FE) [*]

Lecanora symmicta - 1 (MD), 11, 12 (PS)

Lecidella elaeochroma - 1 (MD)

Melanelixia glabratula - 1 (MD) [KO]

Melanelixia fuliginosa s.l. - 11 (rock)

LR:nt Melanelixia subaurifera - 11 (QP)

LR:nt Melanohalea elegantula - 2 (FE), 11 (PS), 13 (TC)

Melanohalea exasperatula - 2 (FE), 12 (PS)

CR Parmelia submontana - 2 (FE), 13 (APi) [KO,*]

Parmelia sulcata $-1,11$ (on various trees), 13 (TC, APi), 14 (wood) [*]

LR:nt Parmelina tiliacea - 2 (FE), 12 (QP)

Parmeliopsis ambigua - 11 (QP), 14 (wood)

Peltigera rufescens -9 (soil) [*]

Pertusaria sp. -12 (QP)

Phaeophyscia orbicularis $-1,2,7,11$ (various substrata, concrete)

Phlyctis argena -1 (MD), 5 (FS), 11 (AP)

Physcia adscendens - 1, 2, 9, 12 (on various trees), 13 (TC)

Physcia aipolia - 1 (MD)

Physcia caesia - 14 (concrete)

Physcia dubia - 11 (rock)

Physcia stelaris - 11 (PS), 13 (TC) [*]

Physcia tenella-1, 2, 11, 12 (on various trees)

Physconia detersa -2 (FE), 11 (PS) [*]

LR:nt Platismatia glauca - 2 (FE) [KO]

EN Pleurosticta acetabulum - 2 (FE), 13 (TC) [KO, *] 
Porpidia albocaerulescens $-5,9$ (rock)

LR:nt Pseudevernia furfuracea - 2 (FE), 7 (PiS, LD), 11, 12 (PS), 13 (TC), 14 (wood) [*]

Ropalospora viridis - 8 (CB) [KO]

VU Usnea hirta - 1 (SC), 12 (PS), 14 (only juvenile, wood) [KO]

Verrucaria muralis -2 (rock)

Verrucaria nigrescens $-2,6,9$ (rock) [*]

LR:nt Xanthoria parietina -1-14, common in the whole area on various substrates

LR:nt Xanthoria polycarpa-12 (PS) [KO]

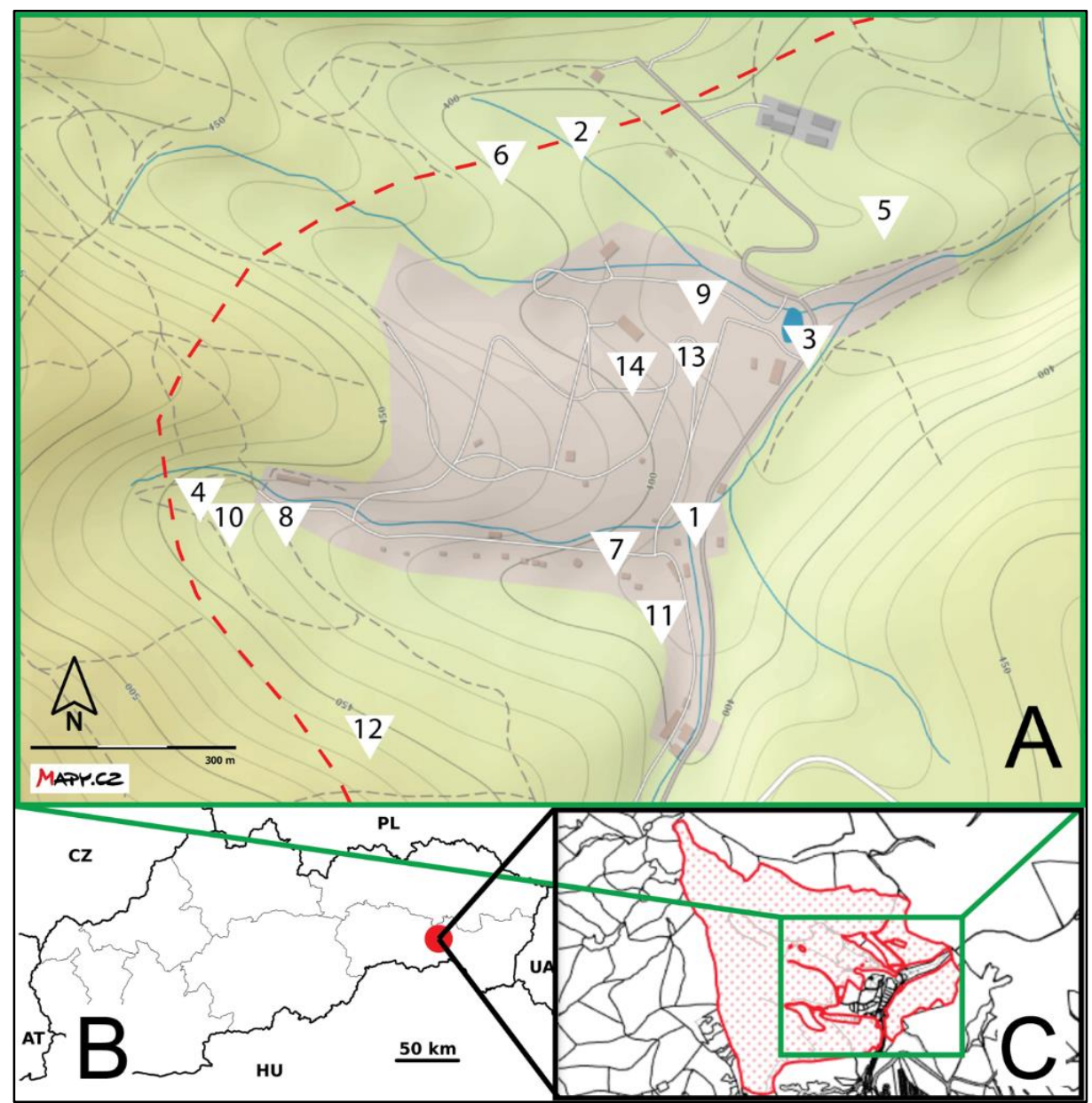

Fig. 1 Košice ZOO. (A) Map of the study locations (1-14), dashed red line marks the border of submontane beech (left) and lowland hygrophilous oak-hornbeam (right) forests. Brown colour represents the area accessible to visitors. (B) Location of the ZOO in Slovakia. (C) Overall size of the ZOO (red). 

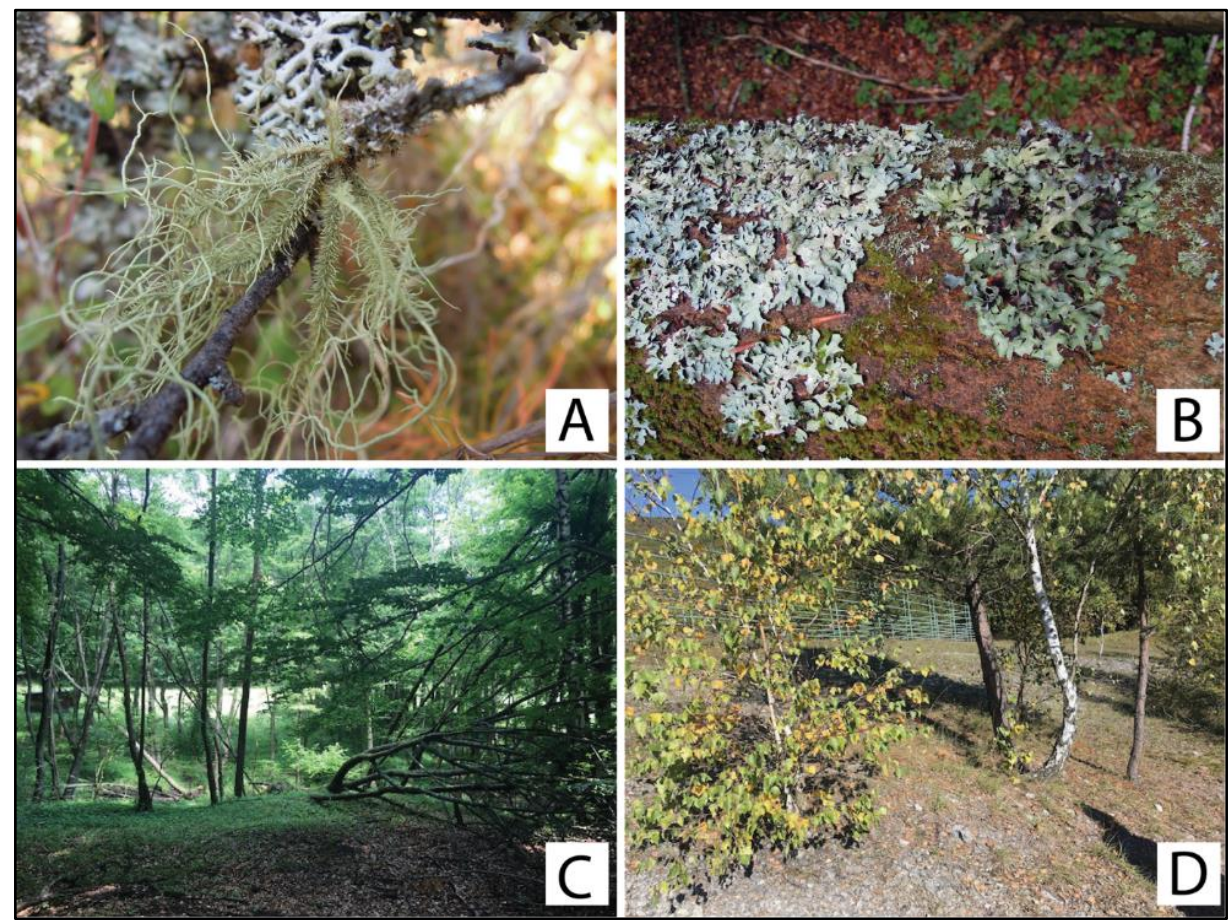

Fig. 2 Selected types of habitats in the area of ZOO Košice. (A) Usnea hirta (loc. 12) growing on Prunus spinosa shrubs; (B) Parmelia sulcata (left) with Parmelia submontana (right) growing on Fraxinus excelsior (loc. 2); (C) General view on loc. 2. with fallen Fraxinus excelsior tree; (D) General view on warm rocky slope (loc. 9).

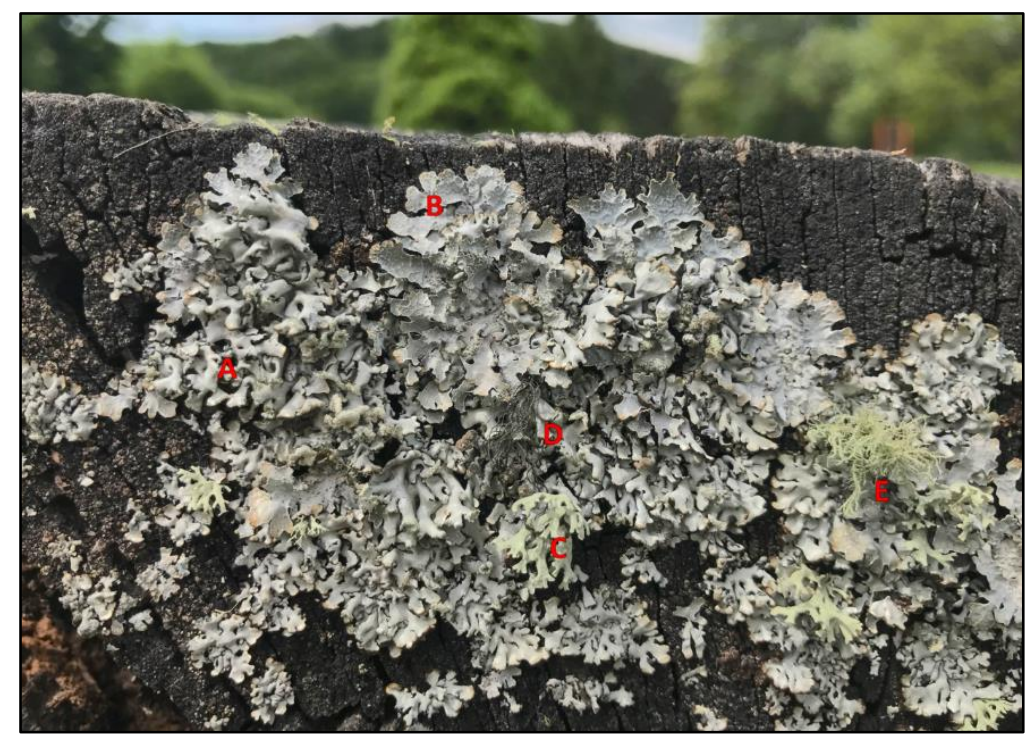

Fig. 3 Location 14, decaying wooden bench. (A) Hypogymnia physodes, (B) Parmelia sulcata, (C) Evernia prunastri, (D) Bryoria sp., (E) Usnea hirta. 


\section{Discussion}

The ZOO Košice offers a broad range of habitats from warm xerothermic slopes, through beech forest and brooks, to concrete paths and animal cages. This variability allows for species diversity within a relatively small area where ubiquitous, nitrophilous but also multiple threatened or rare species occur.

The deeper parts of the beech forest are poor in lichen flora with the exception of several sunlit roadsides (loc. 4, 8, 10). In the central part of the ZOO there are two south-east facing grassy slopes (loc. 6,9 ) inhabited by Cladonia species (C. furcata, C. pyxidata, $C$. subulata and $C$. symphycarpia) which are sporadically mowed (but not grazed). Therefore, nitrogen input is limited to only air-born source. Notably, loc. 6 has a typical limestone-based soil with species Cladonia symphycarpia or epilithic Circinaria contorta. Loc. 9 is an old pile of stones - remnants of a road structure etc. with a mixture of rocks. Most of the trees in the area are deciduous, with only a few Pinus sylvestris trees in loc. 4 and 10 and several planted Larix decidua and Picea abies trees in loc. 7 in the middle of the ZOO. The threatened species Pleurosticta acetabulum growing in the middle of the ZOO on a young Tilia cordata tree trunk with smooth bark along the main routes was found (loc. 13).

Species such as Evernia prunastri, Flavoparmelia caperata and Usnea hirta share a similar habitat and were found together at several locations, frequently on the outer border of the ZOO (loc. 1, 11, 12, 14), on the branches of Prunus spinosa (Fig. 2A), on the bark of Quercus petraea or in an old apple orchard near the entrance to the ZOO. These species are known for their low pollution tolerance to both nitrogen and sulphur (Hawksworth \& Rose 1970). Flavoparmelia caperata was also previously found near the ZOO Košice by Bačkor et al. (2003).

Abundant Graphidion scriptae communities (Graphis scripta combined with Arthonia radiata) in the humid parts of the ZOO were found, mostly on the bark of Carpinus betulus and Fagus sylvatica (loc. 3, 5). Both sites were fully shaded during the summer, humid and close to nitrogen sources, e.g. animal cages.

A significant biodiversity lichen hotspot in the ZOO was found on a single fallen Fraxinus excelsior tree in the forest near the small spring (loc. 2, Fig. 2B, C). Several threatened species such as Evernia prunastri, Flavoparmelia caperata, Melanohalea elegantula, Parmelia submontana, Parmelia tiliacea, Platismatia glauca, Pleurosticta acetabulum, Pseudevernia furfuracea and Xanthoria parietina were found there.

Our record of Parmelia submonata at an altitude of $412 \mathrm{~m}$ a.s.l. is interesting due to the fact that this is the lowest known record of this species in Slovakia. $P$. submontana can be found on bark in montane or supramontane belts at altitudes between 800 to $1500 \mathrm{~m}$. This species occurs throughout whole Slovakia in the Malé Karpaty Mts., the Strážovské vrchy Mts., the Slovenský raj Mts., the Tatry Mts., the Vel'ká Fatra Mts. or in the Bukovské vrchy Mts. (Lisická \& Lackovičová 1998), usually at altitudes over $550 \mathrm{~m}$ (Orthová 2000). Its distribution range in Europe occupies the Mediterranean region, but it was also found in northern Europe in Norway, Lithuania and in Poland at lower altitudes in areas with high humidity. As a result, in southern Europe it is limited to higher altitudes; however, in northern Europe it is also 
common at altitudes of about $300 \mathrm{~m}$, provided that the average precipitation is higher than $600 \mathrm{~mm}$ a year (Motiejūnaite et al. 2003). In Slovakia, P. submontana is considered as critically endangered (Pišút et al. 2001).

Usnea hirta is one of the most common species of this genus in Slovakia. After the decline of heavy industry in 1989, followed by improvements in air quality, this species can be found in urban areas within nitrophilous Xanthorion communities, including apple orchards (Zarabska et al. 2009). We found several occurrences of this species, most of them in juvenile form.

Bryoria is still a poorly known genus in Slovakia (Lisická 2005). According to Guttová et al. (2013), there are 14 species of Bryoria in Slovakia. Bačkor \& Bodnárová (2002) recorded Bryoria species in the Čierna Hora Mts. at Mt. Roháčka without further identification. We have found only one small thallus growing on an old rotten bench, but no sample was taken for further species identification due to little size of thallus on its single locality at this place.

\section{Conclusion}

The Zoological Garden serves as a place for conservation of animal species ex situ and at the same time provides protection for many other species of different organisms. The heterogeneous conditions in different habitats provide suitable environment for a wide spectrum of lichen species, which make the ZOO Košice valuable in terms of lichen conservation. Most of the recorded species are widely distributed and generalist species. Presence of Usnea hirta and Bryoria sp. indicates good air quality. Several endangered species in the Košice ZOO, for example Arthonia radiata, Flavoparmelia caperata, Graphis scripta or Pleurosticta acetabulum were recorded. The lowest altitude for Parmelia submontana in Slovakia was recorded so far. Apparently, lichens may get distinctly more common even in an urban area, if allowed to grow without major disturbance as suggested by Aptroot \& Honegger (2006). Undoubtedly, that this area profits from years of protection thanks to being a part of the $\mathrm{ZOO}$ and surely is worth further investigation, especially in the field of microlichen species.

\section{Acknowledgement}

We would like to thank Erich Kočner (director of ZOO Košice) and Patrik Pastorek (ZOO Košice) for access to the locations beyond the visitor area. This work was supported by Ernst Mach scholarship ICM-2018-11909 (MM). Special thanks go to Róbert Kaffan for his kind improvement of the English text and reviewers for their valuable comments.

\section{References}

Aptroot A. \& Honegger R. (2006): Lichens in the New Botanical Garden of the University of Zürich, Switzerland. - Bot. Helv. 116: 135-148. doi.org/10.1007/s00035-006-0759-6

Bačkor M. \& Bodnárová M. (2002): Additions of lichen flora of Slovak republic I. - Thaiszia J. Bot. 12: 173-178. 
Bačkor M., Paulíková K., Geralská A. \& Davidson R. (2003): Monitoring of air pollution in Košice (Eastern Slovakia) using lichens. - Pol. J. Environ. Stud. 12(2): 141-150.

Biely A., Bezák V., Elečko M., Gross P., Kaličiak M., Konečný V., Lexa J., Mello J., Nemčok J., Polák M., Potfaj M., Rakús M., Vass D., Vozár J. \& Vozárová A. (2017): 4.1.1. Geologická stavba. Atlas krajiny Slovenskej republiky. - Bratislava: Štátny geologický ústav Dionýza Štúra. Available online at http://geo.enviroportal.sk/atlassr/

Faško P. \& Štastný P. (2017): 4.3.7. Priemerné ročné úhrny zrážok. Atlas krajiny Slovenskej republiky. - Bratislava: Štátny geologický ústav Dionýza Štúra. Available online at http://geo.enviroportal.sk/atlassr/

Futák J. (1984): Fytogeografické členenie Slovenska, pp. 418-419 + map (Supplement). - In: Bertová L. (ed.), Flóra Slovenska IV/1. - Veda, Bratislava.

Goga M., Ručová D. \& Marcinčinová M. (2018): Lichens in area of Meteorological and radar station Kojšovská hol'a (Volovec Mountains, SE Slovakia). - Acta Bot. Hung. 60 (1-2): $67-$ 74. DOI: 10.1556/034.60.2018.1-2.5

Guttová A., Lackovičová A. \& Pišút I. (2013): Revised and updated checklist of lichens of Slovakia (May 2013). - Biologia (Bratislava) 68: 845-850 [+ 50 pp electronic appendix]. doi.org/10.2478/s11756-013-0218-y

Guttová A., Fačkovcová Z., Munzi S., Lackovičová A., Pišút I. \& Košuthová A. (2017): Zaujímavejšie floristické nálezy. - In: Eliáš P. ml. (ed.). - Bull. Slov. Bot. Spoločn. 39(2): 204-217.

Hawksworth D. L. \& Rose F. (1970): Qualitative scale for estimating sulphur dioxide air pollution in England and Wales using epiphytic lichens. - Nature 227 (5254): 145-148. doi.org/10.1038/227145a0 Lisická E. (2005): The lichens of the Tatry Mountains. - Veda, Bratislava. 439 p.

Lisická E. \& Lackovičová A. (1998): On lichens in Slovakia. - Sauteria 9: 297-302.

Marhold, K., Mártonfi, P., Mereda, P. \& Mráz, P. (eds.) (2007): Chromosome number survey of the ferns and flowering plants of Slovakia. - Veda, Bratislava.

Matlovičová K., Matlovič R. \& Némethyová B. (2010): City branding as a tool of the local development (Case study of Košice, Slovakia). - Proceedings of Educons University for social science, book 1., The first science symposium with international involvement of Educons University at Sremska Kamenica - Business Economics in Transition, ISBN: 97886-87785-20-5, pp.:127-136.

Motiejūnaitè J., Kukwa M. \& Prigodina-Lukošienè I. (2003): Parmelia submontana in Lithuania and northern Poland. - Graph. Scr. 14: 62-64.

Orthová V. (2000): Nové nálezy Parmelia pastillifera (Harm.) Schub. et Klem. a P. submontana Nádv. ex Hale a ich rozšírenie na Slovensku. - Bryonora 25(5): 13-17.

Orthová V. (2003): Príspevok k poznaniu lišajníkov Volovských vrchov a Čiernej hory. - Bull. Slov. Spoločn. 25, Suppl. 9: 77-86.

Pišút I. (2002): Nachträge zur Kenntnis der Flechten der Slowakei 16. - Acta Rer. Natur. Mus. Nat. Slov. 48: 5-11.

Pišút I. \& Liška J. (1985): Lišajníky Slanských vrchov. - Acta Rer. Natur. Mus. Nat. Slov. 31: 2757.

Pišút I., Guttová A., Lackovičová A. \& Lisická E. (2001): Red list of lichens of Slovakia (December 2001). Červený zoznam rastlín a živočíchov Slovenska. - Ochr. prír., Suppl. 20: 23-30.

Št́astný P., Nieplová E. \& Melo M. (2017): 4.3.17. Priemerná ročná teplota vzduchu. Atlas krajiny Slovenskej republiky. - Bratislava: Štátny geologický ústav Dionýza Štúra. Available online at http://geo.enviroportal.sk/atlassr/ 
Rodrigues-Guerra M. \& Guillén-Salazar F. (2012): The Zoological Park, a new ally for Biodiversity. Guide for the application of law 31/2003* on the conservation of wild fauna in zoological parks (2nd edition). ISBN: 84-695-5469-7

Suza J. (1949): Lišejníky Slovenského Rudohoří. - Acta Acad. Sci. Nat. Moravo-Siles. 21: 1-22. Zarabska D., Guttová A., Cristofolini F., Giordani P. \& Lackovičová A. (2009): Epiphytic lichens of apple orchards in Poland, Slovakia and Italy. - Acta Mycol. 44(2): 151-163.

Received: June $8^{\text {th }} 2020$

Revised: August $4^{\text {th }} 2020$

Accepted: September $22^{\text {nd }} 2020$ 
